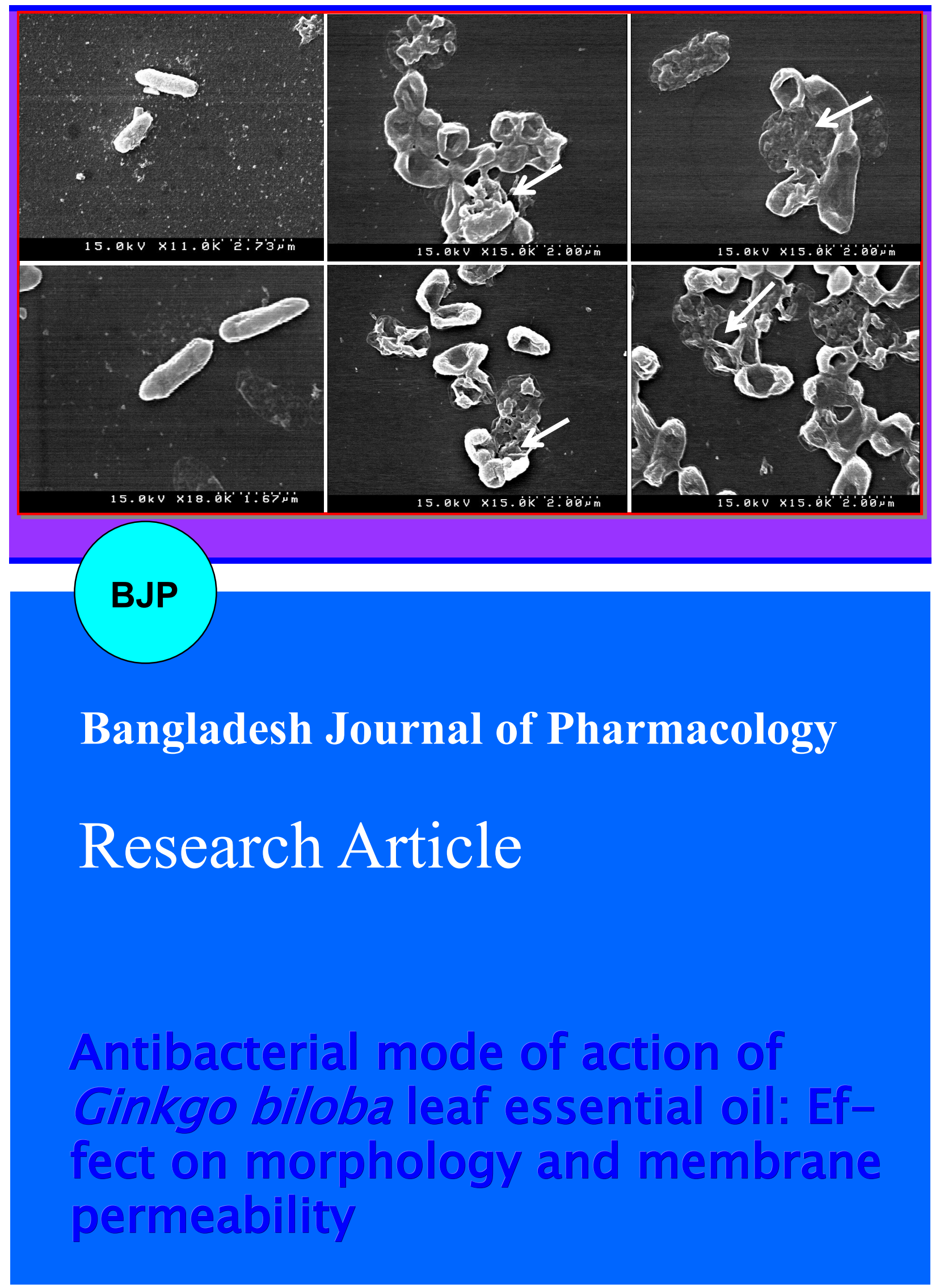




\title{
Antibacterial mode of action of Ginkgo biloba leaf essential oil: Effect on morphology and membrane permeability
}

\author{
Vivek K. Bajpai', Ajay Sharma² and Kwang-Hyun Baek² \\ Department of ${ }^{1}$ Applied Microbiology and ${ }^{2}$ Biotechnology, School of Biotechnology, Yeungnam University, \\ Gyeongsan, Gyeongbuk 712 749, Korea.
}

\begin{tabular}{|c|c|}
\hline \multicolumn{2}{|l|}{ Article Info } \\
\hline Received: & 12 March 2015 \\
\hline Accepted: & 31 March 2015 \\
\hline Available Online: & 18 April 2015 \\
\hline \multicolumn{2}{|c|}{ DOI: 10.3329/bjp.v10i2.22546 } \\
\hline \multicolumn{2}{|c|}{$\begin{array}{l}\text { Cite this article: } \\
\text { Bajpai VK, Sharma A, Baek KH. Anti- } \\
\text { bacterial mode of action of Ginkgo } \\
\text { biloba leaf essential oil: Effect on mor- } \\
\text { phology and membrane permeability. } \\
\text { Bangladesh J Pharmacol. 2015; } 10: 337 \\
-50 \text {. }\end{array}$} \\
\hline
\end{tabular}

\begin{abstract}
This study was aimed to evaluate antimicrobial mode of action of Ginkgo biloba leaf essential oil against food-borne pathogenic bacteria. Gaschromatography and mass-spectrometric analysis determined 34 different compounds, representing $95.4 \%$ of the total oil. The G. biloba leaf essential oil $(1,000 \mu \mathrm{g} /$ disc $)$ showed potential antibacterial effect as diameters of inhibition zones $(12.0 \pm 0.4-18.0 \pm 1.2 \mathrm{~mm})$ along with minimum inhibitory and minimum bactericidal concentration values ranging of $250-1,000 \mu \mathrm{g} / \mathrm{mL}$. Also the G. biloba leaf essential oil had potential inhibitory effect on the cell viability of the tested pathogens. The scanning electron microscopic analysis using G. biloba leaf essential oil showed considerable morphological alterations on the cell wall of tested pathogens. The oil revealed its mode of action on membrane integrity as confirmed by release of extracellular ATP, increase of $260 \mathrm{~nm}$ absorbing materials and increased leakage of potassium ions against food-borne pathogenic bacteria.
\end{abstract}

\section{Introduction}

Illness resulting from consumption of food contaminated with food-borne pathogenic bacteria is a priority concern to public health (Kordali et al., 2005). Various synthetic biocides have been used to control microbial growth and to reduce the incidence of food poisoning and spoilage. However, synthetic antimicrobials are sometimes associated with adversary health effects which have encouraged the development of antimicrobial agents of natural origin including essential oils (Cakir et al., 2005; Leonard et al., 2010). Essential oils are complex mixtures of biologically active volatile substances. Chemically essential oils are teepees and their oxygenated derivatives. In addition, plant-based volatile essential oils and non-volatile secondary metabolites have wide applications in dietary supplements, food flavoring and preservation, folk medicine and fragrance industry (Huang et al., 2005; Kalemba and Kunicka, 2003).

Ginkgo biloba, belonging to family Ginkgoaceae, is an important herb, used in traditional Chinese system of medicine (Huh and Staba, 1992). Extracts of G. biloba leaves have been found to possess anti-diabetic, antiasthmatic, antimicrobial, cardioprotective, hepatoprotective and potent central nervous system activities (Pietri et al., 1997; Mazzanti et al., 2000; Naik and Panda, 2007; Panda and Naik, 2008; Sati and Joshi, 2011). G. biloba contains numerous therapeutically active phyto-constituents such as flavonoids, diterpenes and sesquiterpene lactones which have shown potent scavenging activities (Braquet, 1987; Kleijnen and Knipschild, 1992; Naik et al., 2006; Kaur et al., 2012).

The objective of this study was to investigate the antimicrobial mode of action of G. biloba leaf essential oil against food-borne pathogens in various in vitro models.

\section{Materials and Methods \\ Chemicals and instrument}


The standard tetracycline and other chemicals were purchased from Sigma-Aldrich (St. Louis, USA) or Merck (NJ, USA). Spectrophotometric measurements were done by using a 96-well microplate enzyme-linked immunosorbent assay reader (Infinite M200, Tecan, Mannedorf, Switzerland) and a luminometer (Synergy HT Multi-Mode Microplate Reader, Biotek, VT, USA).

\section{Plant material and extraction}

Dried leaves of G. biloba (200 g), which was collected from the campus of Yeungnam University in November 2011 were subjected to hydrodistillation using a microwave extraction apparatus for a period of 2 hours. The microwave extraction apparatus was purchased from the Korea Microwave and Dry Engineering Company, Yangju city, Korea. The distillate was collected and mixed with dichloromethane, shaken and kept in a separating funnel. The lower layer of dichloromethane containing the essential oil was collected and evaporated at room temperature. Finally, the oil was dried over anhydrous $\mathrm{Na}_{2} \mathrm{SO}_{4}$ and preserved in a sealed vial at $4^{\circ} \mathrm{C}$ until tested and analyzed.

\section{Gas chromatography-mass spectrometry (GC-MS) analysis}

The detailed chemical composition analysis of the G. biloba leaf essential oil was carried out using a GC/MS system (Jeol JMS 700 mass spectrometer equipped with an Agilent 6890N GC) using a DB-5 MS fused silica capillary column $(30 \mathrm{~m} \times 0.25 \mathrm{~m}$ i.d., film thickness 0.25 $\mu \mathrm{m})$. For GC-MS detection, an electron ionization system with ionization energy of $70 \mathrm{eV}$ was used. Helium gas was used as the carrier gas at a constant flow rate of $1 \mathrm{~mL} / \mathrm{min}$. Injector and MS transfer line temperature were set at 280 and $250^{\circ} \mathrm{C}$, respectively. The initial oven temperature of $50^{\circ} \mathrm{C}$ was maintained for $2 \mathrm{~min}$, and then increased to $250^{\circ} \mathrm{C}$ at a rate of $10^{\circ} \mathrm{C} /$ min followed by holding at $250^{\circ} \mathrm{C}$ for $10 \mathrm{~min}$. Diluted samples $(1 / 100 \mathrm{v} / \mathrm{v}$, in methanol) of $1.0 \mu \mathrm{L}$ were injected manually in the splitless mode. The relative percentage of the oil constituents was expressed as percentages by peak area normalization. Identification of essential oil components was based on GC retention time on a DB-5 capillary column relative to computer matching of mass spectra using Wiley and NIST libraries for the GC-MS system (Adam, 2001).

\section{Microbial strains}

The following microorganisms as food-borne pathogenic bacteria were used in this study which included Listeria monocytogenes ATCC 7644, Salmonella typhimurium ATCC 43174, Escherichia coli ATCC 43889, Staphylococcus aureus ATCC 12600 and Bacillus cereus ATCC 13061. The bacterial pathogens were obtained from the Korea Food and Drug administration (KFDA), which were maintained on nutrient agar medium at $4^{\circ}$ C.

\section{Determination of antibacterial activity}

Standard agar diffusion method was used for the determination of antibacterial efficacy of G. biloba leaf essential oil (Bajpai et al., 2009). Petri plates were prepared by pouring $20 \mathrm{~mL}$ of nutrient agar medium and allowed to solidify. Plates were dried and $1 \mathrm{~mL}$ of standardized inoculum containing $10^{7} \mathrm{CFU} / \mathrm{mL}$ of bacterial suspension was poured and uniformly spread, and the inoculum was allowed to dry for $5 \mathrm{~min}$. A Whatman No. 1 sterile filter paper disc (6 mm diameter) was impregnated with $1,000 \mu \mathrm{g} /$ disc of GBEO. The GBEO was dissolved in 5\% dimethylsulphoxide. Negative controls were prepared using dimethylsulfoxide. Standard reference antibiotic, tetracycline (20 $\mu \mathrm{g} /$ disc) was used as positive control against the tested food-borne pathogenic bacteria. The plates were incubated at $37^{\circ} \mathrm{C}$ for 24 hours. Anti-bacterial activity was evaluated by measuring the diameter of inhibition zones against the tested bacteria. Each assay in this experiment was performed in triplicate.

\section{Determination of minimum inhibitory and minimum bactericidal concentrations}

The minimum inhibitory concentration of G. biloba leaf essential oil was tested by 2 -fold serial dilution method (Bajpai et al., 2009). The G. biloba leaf essential oil was first dissolved in DMSO and incorporated into nutrient broth medium for bacterial pathogens to obtain a concentration of $2000 \mu \mathrm{g} / \mathrm{mL}$, and serially diluted to achieve 1,000, 500, 250, 125, 62.5, 31.25, 15.62 and 7.81 $\mu \mathrm{g} / \mathrm{mL}$, respectively. A $10 \mu \mathrm{L}$ standardized suspension of each tested organism (approximately $10^{7} \mathrm{CFU} / \mathrm{mL}$ ) was transferred to each tube. The control tubes containing only bacterial suspensions were incubated at $37^{\circ} \mathrm{C}$ for 24 hours. The lowest concentration of the GBEO, which did not show any visible growth of test organisms after macroscopic evaluation, was determined as MIC, which was expressed in $\mu \mathrm{g} / \mathrm{mL}$. Further, the concentrations showing complete inhibition of visual growth of bacterial pathogens were identified, and $50 \mu \mathrm{L}$ of each culture broth was transferred on to the agar plates and incubated for specified time and temperature as mentioned above. The complete absence of growth of bacterial colonies on the agar surface is the lowest concentration of sample and was defined as the minimum bactericidal concentration. Each assay in this experiment was replicated three times.

\section{Effect of GBEO on viable count of bacterial pathogens}

Active cultures for viable count assay were prepared in nutrient broth medium. For each strain, $1 \mathrm{~mL}$ of active stock solution was transferred to $4 \mathrm{~mL}$ of nutrient broth. All treated cultures were kept at $37^{\circ} \mathrm{C}$ for 2 hours. The cultures were then centrifuged at $10,000 \mathrm{~g}$ for $10 \mathrm{~min}$. The pellets were retained and re-suspended with $1 \mathrm{~mL}$ of phosphate buffer saline. For viable counts, each of 
the tubes containing re-suspended bacterial suspension (approximately $10^{7} \mathrm{CFU} / \mathrm{mL}$ ) of B. cereus ATCC 13061 and E. coli ATCC 43889 was inoculated with $100 \mu \mathrm{L}$ essential oil at MIC concentration in $900 \mu \mathrm{L}$ NB broth, and kept at $37^{\circ} \mathrm{C}$. Samples for viable cell counts were taken out at $0,40,80,120,160$ and $200 \mathrm{~min}$ time intervals. The viable plate counts were monitored as followed: after incubation, $100 \mu \mathrm{L}$ of the re-suspended culture was diluted into $900 \mu \mathrm{L}$ PBS, there by diluting it 10-fold. A $100 \mu \mathrm{L}$ sample of each treatment was diluted and spread on the surface of nutrient broth agar. The colonies were counted after 24 hours of incubation at $37^{\circ} \mathrm{C}$ (Bajpai et al., 2009). The controls were inoculated without compound for each bacterial strain with the same experimental condition as mentioned above. Each assay in this experiment was replicated three times.

\section{Scanning electron microscopic analysis}

To determine the efficacy of G. biloba leaf essential oil on the morphology of B. cereus ATCC 13061 and E. coli ATCC 43889, a scanning electron microscopic study was performed using the minimum inhibitory concentration of G. biloba leaf essential oil. Control samples were prepared without the G. biloba leaf essential oil. Further, to observe the morphological changes, the SEM was modified from the Kockro method (Kockro et al., 2000; Bajpai et al., 2009). The bacterial sample was washed gently with $50 \mathrm{mM} / \mathrm{L}$ phosphate buffer solution ( $\mathrm{pH} 7.2$ ), fixed with $2.5 \%, 100$ $\mathrm{mL}$ glutaraldehyde and $100 \mathrm{~mL}$ osmic acid solution $(1 \%)$. The specimen was dehydrated using sequential exposure per ethanol concentrations ranging from 50$100 \%$. The ethanol was replaced by tertiary butyl alcohol. After dehydration, the specimen was dried with carbon dioxide $\left(\mathrm{CO}_{2}\right)$. Finally, the specimen was sputter-coated with gold in an ion coater for 2 min, followed by microscopic examinations (S-4300; Hitachi, Hitachi City, Japan).

\section{Measurement of extracellular adenosine 5'-triphophate concentration}

To determine the efficacy of G. biloba leaf essential oil on the membrane integrity, concentration of extracellular adenosine 5'-triphophate (ATP) was measured according to the method described previously (Lee et al., 2002). The working culture of B. cereus ATCC 13061 and E. coli ATCC 43889 containing approximately $10^{7}$ $\mathrm{CFU} / \mathrm{mL}$ were centrifuged for $10 \mathrm{~min}$ at $1,000 \mathrm{~g}$ and the supernatants were removed. The cell pellets were washed three times with $0.1 \mathrm{~mol} / \mathrm{L}$ of sodium phosphate buffer $(\mathrm{pH} 7)$ and then cells were collected by centrifugation under the same conditions. A cell suspension $\left(10^{7} \mathrm{CFU} / \mathrm{mL}\right)$ was prepared with $9 \mathrm{~mL}$ of sodium phosphate buffer $(0.1 \mathrm{~mol} / \mathrm{L}, \mathrm{pH} 7)$ and $0.5 \mathrm{~mL}$ of cell suspension was taken into the Eppendorf tube for the treatment of G. biloba leaf essential oil. Then, the different concentrations (control and minimum inhibitory concentration) of G. biloba leaf essential oil were added to the cell suspension. Samples were maintained at room temperature for $30 \mathrm{~min}$, centrifuged for $5 \mathrm{~min}$ at 2,000 $\mathrm{g}$, and incubated in ice immediately to prevent the ATP loss until measurement. The extracellular (upper layer) adenosine 5'-triphophate concentrations were measured using an ATP bioluminescent assay kit (Sigma, MO, USA) which comprised ATP assay mix containing luciferase, luciferin, magnesium sulfate, dithiothreitol, ethylenediamine tetraacetic acid, bovine serum albumin and tricine buffer salts. The ATP concentration of the supernatants, which represents the extracellular concentration, was determined using a luminometer (Synergy HT Multi-Mode Microplate Reader, Biotek, VT, USA) after the addition of $100 \mu \mathrm{L}$ of ATP assay mix to $100 \mu \mathrm{L}$ of bacterial supernatant. The emission and excitation wavelengths were 520 and $420 \mathrm{~nm}$; excitation band pass and emission band pass were 1 and $2 \mathrm{~nm}$, respectively.

\section{Measurement of release of $260 \mathrm{~nm}$ absorbing cellular} materials

The measure of the release of $260 \mathrm{~nm}$ absorbing materials from B. cereus ATCC 13061 and E. coli ATCC 43889 cells was carried out in aliquots of $2 \mathrm{~mL}$ of the bacterial inoculum in sterile peptone water $(0.1 \mathrm{~g} / 100$ $\mathrm{mL}$ ) added of $G$. biloba leaf essential oil (minimum inhibitory concentration) at $37^{\circ} \mathrm{C}$. At 0,30 and $60 \mathrm{~min}$ of treatment, cells were centrifuged at $3,500 \mathrm{~g}$, and the absorbance of the obtained supernatant was determined at $260 \mathrm{~nm}$ by a 96-well plate enzyme-linked immunosorbent assay reader (Infinite M200, Tecan, Mannedorf, Switzerland) as described by Carson et al. ( 2002). Control flasks without G. biloba leaf essential oil were tested similarly. Results were expressed in terms of optical density of $260 \mathrm{~nm}$ absorbing materials in each interval with respect to the ultimate time.

\section{Assay of potassium ions efflux}

A previously described method was used to determine the amount of potassium ions (Lee et al., 2002). The concentration of free potassium ions in bacterial suspensions of B. cereus ATCC 13061 and E. coli ATCC 43889 was measured after exposure to the G. biloba leaf essential oil at minimum inhibitory concentration in sterile peptone water $(0.1 \mathrm{~g} / 100 \mathrm{~mL})$ for $0,30,60$ and $120 \mathrm{~min}$. At each pre-established interval, the extracellular potassium concentration was measured by a photometric procedure using the Kalium/Potassium kit (Quantofix, GmbH, Wiesbaden, Germany). Control flasks without GBEO were tested similarly. Results were expressed as amount of extracellular free potassium $(\mathrm{mmol} / \mathrm{L})$ in the growth media in each interval of incubation.

\section{Statistical analysis}

All data are expressed as the mean \pm SD by measuring three independent replicates. Analysis of variance using 
one-way ANOVA followed by Duncan's test was performed to test the significance of differences between means obtained among the treatments at the
$5 \%$ level of significance using a SAS software (Version: SAS 9.2, SAS Institute Inc., Cary, NC, USA).

\begin{tabular}{|c|c|c|c|c|c|}
\hline \multicolumn{6}{|c|}{ Table I } \\
\hline \multicolumn{6}{|c|}{ Chemical composition analysis of the microwave-assisted leaf essential oil of G. biloba } \\
\hline No. & SIa & $\mathrm{RT}^{\mathrm{b}}$ & Compoundc & Composition (\%) ${ }^{\mathrm{d}}$ & Identification methode \\
\hline 1 & 415 & 1.40 & Boronic acid & 4.91 & EI-MS \\
\hline 2 & 466 & 1.44 & Scyllitol & 15.50 & EI-MS \\
\hline 3 & 860 & 1.49 & Boric acid & 6.62 & EI-MS \\
\hline 4 & 453 & 1.54 & Germane & 4.48 & EI-MS \\
\hline 5 & 898 & 5.95 & Phenethyl alcohol & 4.09 & EI-MS \\
\hline 6 & 571 & 6.65 & 1,1-dimethoxy-2-chloro-2-propene & 0.39 & EI-MS \\
\hline 7 & 665 & 7.01 & Thymol & 0.85 & EI-MS \\
\hline 8 & 582 & 7.08 & 1-octanol & 0.09 & EI-MS \\
\hline 9. & 467 & 7.80 & 4-phenyldodecane & 0.28 & EI-MS \\
\hline 10 & 419 & 8.28 & 6-methyl-1,2,5-heptatrien-4-ol & 0.35 & EI-MS \\
\hline 11 & 912 & 11.31 & $\beta$-selinene & 1.60 & EI-MS \\
\hline 12 & 733 & 11.41 & $\gamma$-gurjunene & 0.41 & EI-MS \\
\hline 13 & 821 & 11.51 & Butylated hydroxyl toluene & 0.97 & EI-MS \\
\hline 14 & 569 & 12.42 & Valerenol & 4.23 & EI-MS \\
\hline 15 & 794 & 12.46 & Ethylpthalate & 26.47 & EI-MS \\
\hline 16 & 643 & 12.51 & trans-caryophyllene & 2.68 & EI-MS \\
\hline 17 & 685 & 12.61 & Veridiflorol & 0.40 & EI-MS \\
\hline 18 & 585 & 12.81 & 3-menthene & 0.52 & EI-MS \\
\hline 19 & 626 & 12.84 & Juniper camphor & 0.50 & EI-MS \\
\hline 20 & 611 & 13.29 & $\beta$-eudesmol & 0.84 & EI-MS \\
\hline 21 & 597 & 13.32 & t-cadinol & 0.66 & EI-MS \\
\hline 22 & 424 & 13.51 & Z-jasmone & 0.29 & EI-MS \\
\hline 23 & 524 & 13.54 & Cetal & 0.77 & EI-MS \\
\hline 24 & 474 & 14.24 & Isolongifolineoxide & 0.82 & EI-MS \\
\hline 25 & 531 & 14.32 & Platambin & 0.98 & EI-MS \\
\hline 26 & 579 & 14.37 & Aristolone & 0.69 & EI-MS \\
\hline 27 & 355 & 14.71 & Urea & 0.43 & EI-MS \\
\hline 28 & 282 & 14.74 & Tartaric acid & 0.37 & EI-MS \\
\hline 29 & 455 & 16.02 & 4,4-diphenyl-5-methyl-2-cyclohexenone & 2.53 & EI-MS \\
\hline 30 & 571 & 16.40 & 5,7-dimethoxy-2,2-dimethyl-2H-chromene & 0.85 & EI-MS \\
\hline 31 & 305 & 16.74 & 1,2-dimethylquinoline & 1.58 & EI-MS \\
\hline 32 & 413 & 16.77 & 6-azidochrysene & 1.85 & EI-MS \\
\hline 33 & 325 & 17.37 & Maculosidine & 0.92 & EI-MS \\
\hline 34 & 294 & 24.65 & Di-desethylflurazepam & 6.53 & EI-MS \\
\hline
\end{tabular}

aNIST library search purity values; bRetention time (RT); cCompounds listed in order of elution from a DB-5 capillary column; dPercentage based on FID peak area normalization $(n=3)$; eIdentification based on computer matching of electron ionization mass-spectra using Wiley and NIST libraries for the GC-MS system 


\begin{tabular}{|c|c|c|}
\hline \multicolumn{3}{|c|}{ Table II } \\
\hline \multicolumn{3}{|c|}{$\begin{array}{l}\text { Antibacterial activity of } G \text {. biloba leaf essential oil } \\
\text { against food-borne pathogens }\end{array}$} \\
\hline \multirow{2}{*}{$\begin{array}{l}\text { Bacterial patho- } \\
\text { gen }\end{array}$} & \multicolumn{2}{|c|}{ Diameter of inhibition zone $(\mathrm{mm})$} \\
\hline & $\begin{array}{l}\text { G. biloba leaf } \\
\text { essential oil }\end{array}$ & Tetracycline \\
\hline $\begin{array}{l}\text { Bacillus cereus } \\
\text { ATCC } 13061\end{array}$ & $18.0 \pm 1.2^{\mathrm{a}}$ & $25.5 \pm 0.07 \mathrm{c}$ \\
\hline $\begin{array}{l}\text { Listeria monocyto- } \\
\text { genes ATCC } 7644\end{array}$ & $14.0 \pm 0.3^{b}$ & $27.0 \pm 0.7^{b}$ \\
\hline $\begin{array}{c}\text { Staphylococcus } \\
\text { aureus ATCC } \\
12600\end{array}$ & $17.0 \pm 0.8^{a}$ & $22.0 \pm 0.2^{a}$ \\
\hline $\begin{array}{c}\text { Salmonella typhi- } \\
\text { murium ATCC } \\
43174\end{array}$ & $12.0 \pm 0.4^{c}$ & $12.5 \pm 0.2 \mathrm{e}$ \\
\hline $\begin{array}{c}\text { Escherichia coli } \\
\text { ATCC } 43889\end{array}$ & $14.0 \pm 0.6^{\mathrm{b}}$ & $14.4 \pm 0.7^{\mathrm{d}}$ \\
\hline
\end{tabular}

\section{Results}

The GC-MS analysis of the G. biloba leaf essential oil led to the identification of 34 different components, representing $95.5 \%$ of the total oil (Table I). The microwave-assisted hydrodistillation of G. biloba leaf yielded light yellowish oil with the major composition of the oil containing terpenes and their oxygenated derivatives, aliphatic and aromatic hydrocarbons, along with some other oxygenated essential phytochemicals. The major components detected in the oil were ethylpthalate $(26.5 \%)$, boric acid $(6.6 \%)$, didesethylflurazepam dehydration product $(6.5 \%)$, boronic acid $(4.9 \%)$, germane $(4.5 \%)$, valerenol $(4.2 \%)$, phenethyl alcohol $(4.1 \%)$, trans-caryophyllene $(2.7 \%)$, 4,4-diphenyl -5-methyl-2-cyclohexenone $(2.5 \%), \quad 6$-azidochrysene $(1.9 \%), 1,2$-dimethylquinoline $(1.6 \%), \beta$-selinene $(1.6 \%)$, platambin $(1.0 \%)$, butylated hydroxy toluene $(1.0 \%)$ maculosidine $(0.9 \%)$ and thymol $(0.9 \%)$. The GBEO was also found to contain aristolone $(0.7 \%)$, $\mathrm{t}$-cadinol $(0.7 \%)$, urea $(0.4 \%)$, and tartaric acid $(0.4 \%)$ as the trace components of G. biloba leaf essential oil in the present study.

The antibacterial activity of GBEO against the tested foodborne pathogenic bacteria was qualitatively and quantitatively determined by the presence or absence of inhibition zones. As presented in Table II, G. biloba leaf essential oil $(1,000 \mu \mathrm{g} /$ disc) exhibited potent inhibitory effect against the tested food-borne pathogenic bacteria. In this assay, B. cereus ATCC 13061, S. aureus ATCC 12600 and L. monocytogenes ATCC 7644 were found to be the most inhibited bacterial pathogens by the $G$. biloba leaf essential oil with their respective diameters of inhibition zones of $18 \pm 1.2,17 \pm 0.8,14 \pm 0.3 \mathrm{~mm}$, where -as E. coli ATCC 43889 and $S$. typhimurium ATCC 43174 were inhibited moderately with diameters of

\begin{tabular}{|c|c|c|}
\hline \multicolumn{3}{|l|}{ Table III } \\
\hline \multicolumn{3}{|c|}{$\begin{array}{l}\text { Determination of minimum inhibitory (MIC) and } \\
\text { minimum bactericidal (MBC) values of G. biloba } \\
\text { leaf essential oil against food-borne pathogens }\end{array}$} \\
\hline \multirow[t]{2}{*}{ Bacterial pathogen } & \multicolumn{2}{|c|}{$\begin{array}{c}\text { G. biloba leaf essen- } \\
\text { tial oil }\end{array}$} \\
\hline & $\mathrm{MIC}^{\mathrm{b}}$ & $\mathrm{MBC}$ \\
\hline Bacillus cereus ATCC 13061 & 250 & 500 \\
\hline Listeria monocytogenes ATCC 7644 & 250 & 500 \\
\hline Staphylococcus aureus ATCC 12600 & 250 & 500 \\
\hline Salmonella typhimurium ATCC 43174 & 500 & 1,000 \\
\hline Escherichia coli ATCC 43889 & 500 & 1,000 \\
\hline
\end{tabular}

inhibition zones of $14.0 \pm 0.6$ and $12.0 \pm 0.4 \mathrm{~mm}$, respectively (Table II). The G. biloba leaf essential oil exhibited significant and almost similar antibacterial effect as did by standard compound tetracycline at the used concentration. In this assay, the diameters of inhibition zones of G. biloba leaf essential oil against Gram positive bacteria were found to be higher than Gram negative bacteria (Table I). The dimethylsulfoxide, as a negative control had no inhibitory effect at the used concentration.

The G. biloba leaf essential oil showed potent inhibitory effect as minimum inhibitory and minimum bactericidal concentration values against all the tested foodborne pathogenic bacteria. As shown in Table III, the minimum inhibitory and minimum bactericidal concentration values of G. biloba leaf essential oil against the tested Gram positive bacteria of B. cereus ATCC 13061, L. monocytogenes ATCC 7644 and S. aureus ATCC 12600 were found in the range of 250 to $500 \mu \mathrm{g} / \mathrm{mL}$, while for Gram negative bacteria such as $S$. typhimurium ATCC 43174 and E. coli ATCC 43889, the MIC and MBC values were ranged from 500 to $1000 \mu \mathrm{g} / \mathrm{mL}$. In this assay, B. cereus ATCC 13061, L. monocytogenes ATCC 7644, and S. aureus ATCC 12600 were found extremely susceptible pathogens to the G. biloba leaf essential oil with their respective MIC and MBC values of (250, 250 and $250 \mu \mathrm{g} / \mathrm{mL}$ ) and (500, 500 and $500 \mu \mathrm{g} / \mathrm{mL}$ ), respectively. Although both Gram positive and Gram negative bacteria were found susceptible to G. biloba leaf essential oil in this study, S. typhimurium ATCC 43174 and E. coli ATCC 43889 showed less susceptibility to G. biloba leaf essential oil.

Based on the sensitivity of the test food-borne pathogens, one Gram positive (B. cereus ATCC 1306) and a Gram negative (E. coli ATCC 43889) bacteria were selected as the model organisms for further studies to confirm the antibacterial mode of action of G. biloba leaf essential oil. In this regard, further study was carried out to evaluate the effect of GBEO on the viable counts of the selected bacteria such as B. cereus ATCC 13061 and E. coli ATCC 43889. The effect of G. biloba leaf 


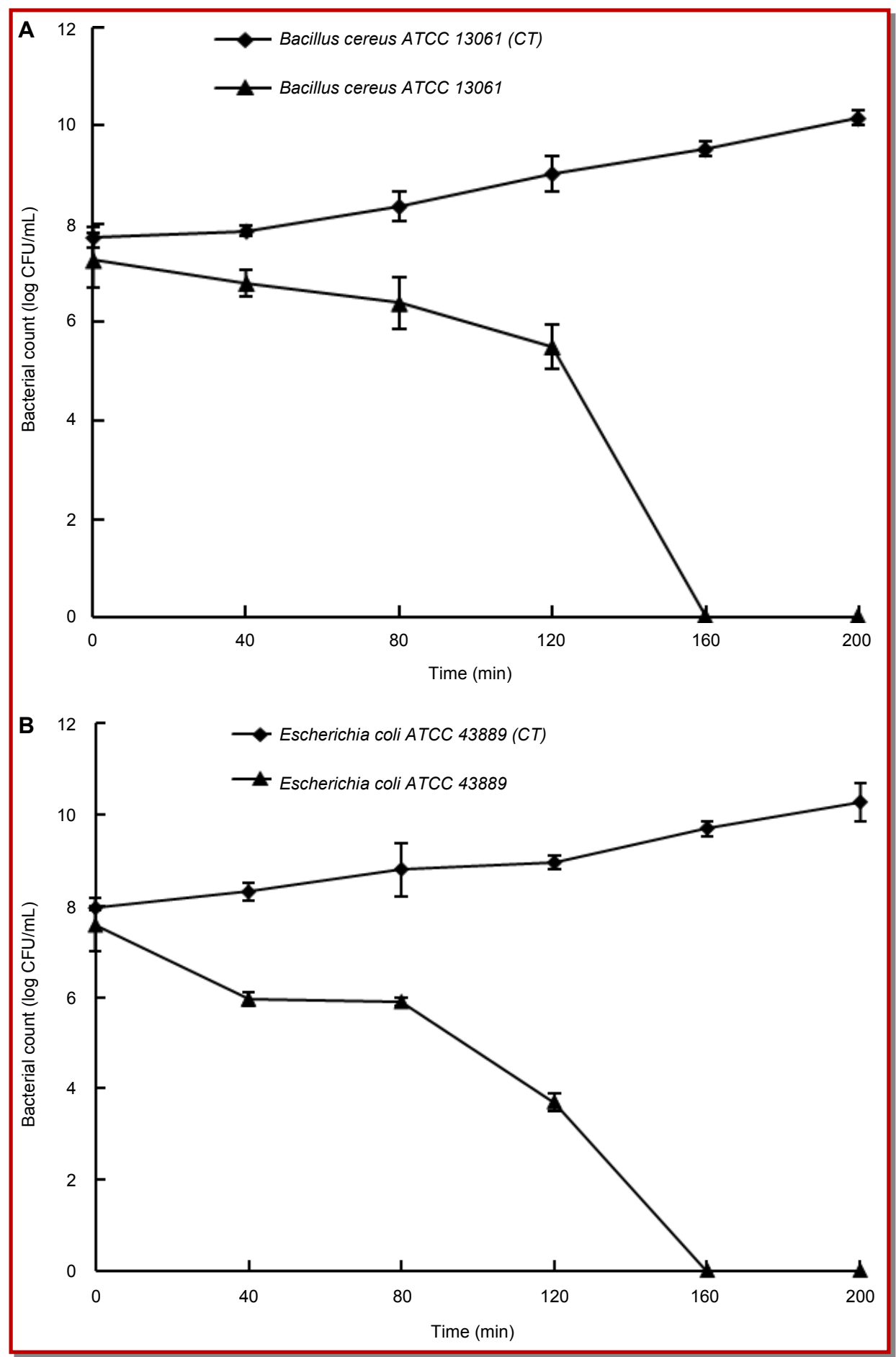

Figure 1: Effect of the Ginkgo biloba leaf essential oil on the viability of the tested food-borne pathogenic bacteria of B. cereus ATCC 13061 (A) and E. coli ATCC 43889 (B); CT: control without treatment

essential oil on the growth of tested bacterial pathogens demonstrated reduced viability at the used concentration (Figure 1). The exposure of 0 to $80 \mathrm{~min}$ of $G$. biloba leaf essential oil did not cause severe decline on the inhibition of cell viability of the tested pathogens, however, considerable amount of inhibitory effect was observed on the inhibition of the cell viability of the tested bacteria of E. coli ATCC 43889 and B. cereus ATCC 13061 at the exposure time of $120 \mathrm{~min}$. Interestingly, the exposure of the G. biloba leaf essential oil for $160 \mathrm{~min}$ revealed complete inhibition of colony forming unit numbers against B. cereus ATCC 13061 

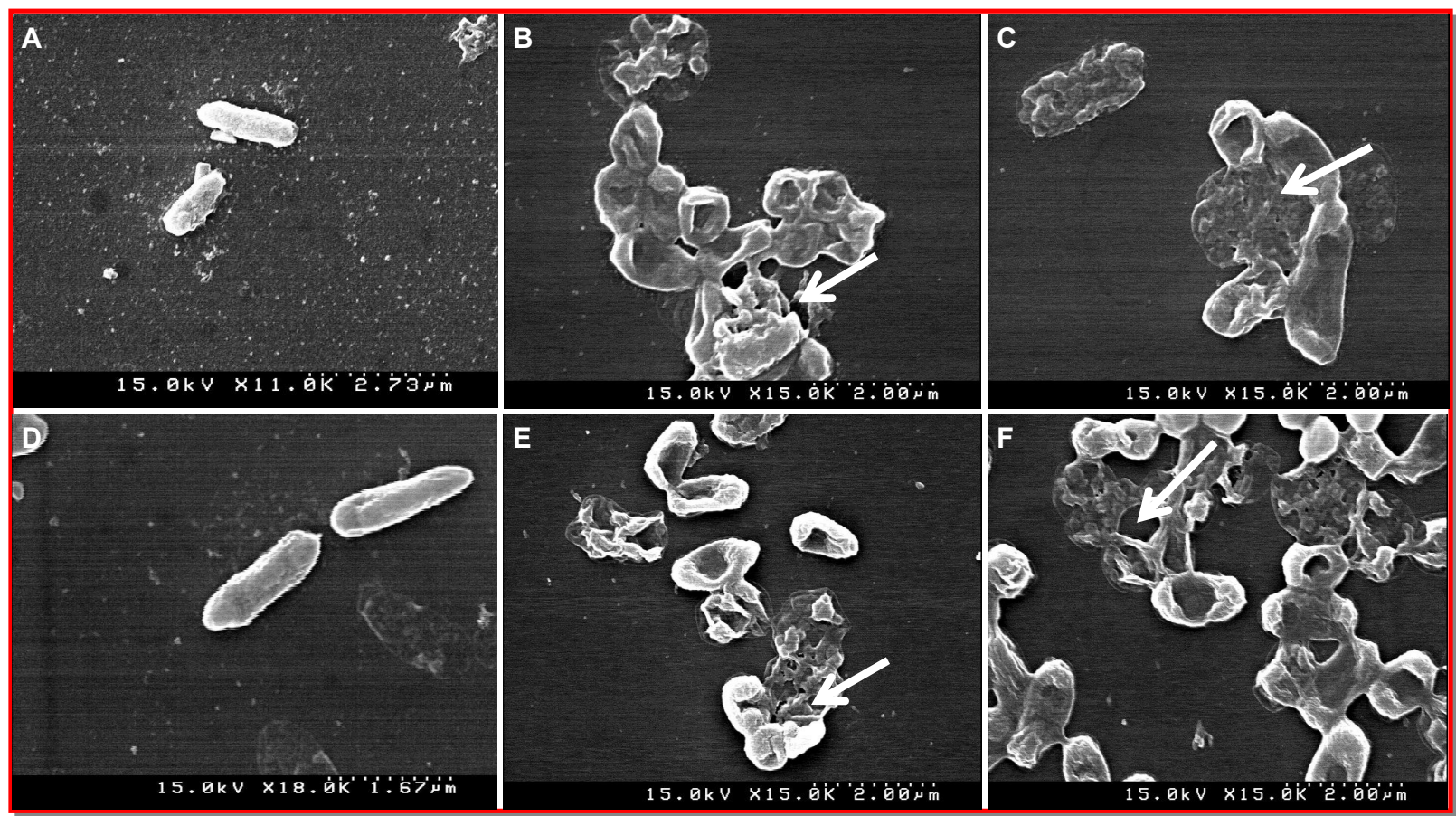

Figure 2: Pictures of the scanning electron microscopy of B. cereus ATCC 13061 (A, B, C) and E. coli ATCC 43889 (D, E, F) treated with the G. biloba leaf essential oil

A, D: Controls, showing a regular and smooth surface; B, E: disruption and swelling of the cells; C, F: surface collapse or lysed cell formation

(Figure 1a). On the other hand, complete inhibition of cell viable counts of E. coli ATCC 43889 was observed at 200 min exposure time of GBEO, and no colony forming unit formation was observed (Figure 1b).

Physical and morphological alterations may encounter the cell wall surface deterioration of bacterial pathogens when treated with a suitable antimicrobial agent. Hence, a scanning electron microscopic analysis was carried out to further visualize the effect of G. biloba leaf essential oil on the morphology of B. cereus ATCC 13061 and E. coli ATCC 43889 cells as compared to control group (Figure 2). Control cells of the test food-borne pathogens in the absence of G. biloba leaf essential oil showed a regular and smooth surface (Figure 2a,d). In contrast, B. cereus ATCC 13061 and E. coli ATCC 43889 cells treated with GBEO at minimum inhibitory concentration (250 and $500 \mu \mathrm{g} / \mathrm{mL}$, respectively) revealed severe damaging effect on the cell morphology of the tested pathogens, showing disruption of cell membrane and swelling of the cells (Figure 2b,e). Moreover, initial exposure of G. biloba leaf essential oil to the tested foodborne pathogenic bacteria revealed large surface collapse and abnormal cell breaking, as well as complete lysis or dead cell formation (Figure $2 \mathrm{c}, \mathrm{f})$.

The effect of G. biloba leaf essential oil on the determination of the concentration of extracellular adenosine 5' -triphophatein B. cereus ATCC 13061 and E. coli ATCC 43889 cells is presented in Figure 3. The extracellular adenosine 5 '-triphophate concentrations in the untreated cells (control) of B. cereus ATCC 13061 and E. coli ATCC 43889 were found to be 0.3 and 0.9 $\mathrm{pg} / \mathrm{mL}$, respectively (Figure 3). B. cereus ATCC 13061 and E. coli ATCC 43889 cells treated with G. biloba leaf essential oil at minimum inhibitory concentration showed significant $(\mathrm{p}<0.05)$ increase in the release of extracellular ATP concentrations. At minimum inhibitory concentration of G. biloba leaf essential oil, the extracellular adenosine 5'-triphophate concentrations for B. cereus ATCC 13061 and E. coli ATCC 43889 cells were found to be 9.5 (Figure 3a) and 9.3 (Figure 3b) pg/mL, respectively (Figure 3). Destabilization of the plasma membrane and/or leakage of ions are expected to have an impact on the membrane-associated energy-transducing system. It was confirmed that G. biloba leaf essential oil had detrimental effect on damaging cell membrane integrity, resulting in the increased extracellular ATP concentration from the treated cells.

Further antibacterial mode of action of G. biloba leaf essential oil against the tested food-borne pathogens was confirmed using the assay for release of potassium ions from the treated cells of B. cereus ATCC 13061 and E. coli ATCC 43889 (Figure 4). In this assay, the release of potassium ions from the bacterial cells occurred immediately after the addition of G. biloba leaf essential oil at minimum inhibitory concentration following a sturdy loss along the specified intervals (Figure $4 a, b$ ). However, no leakage of potassium ion was observed in 


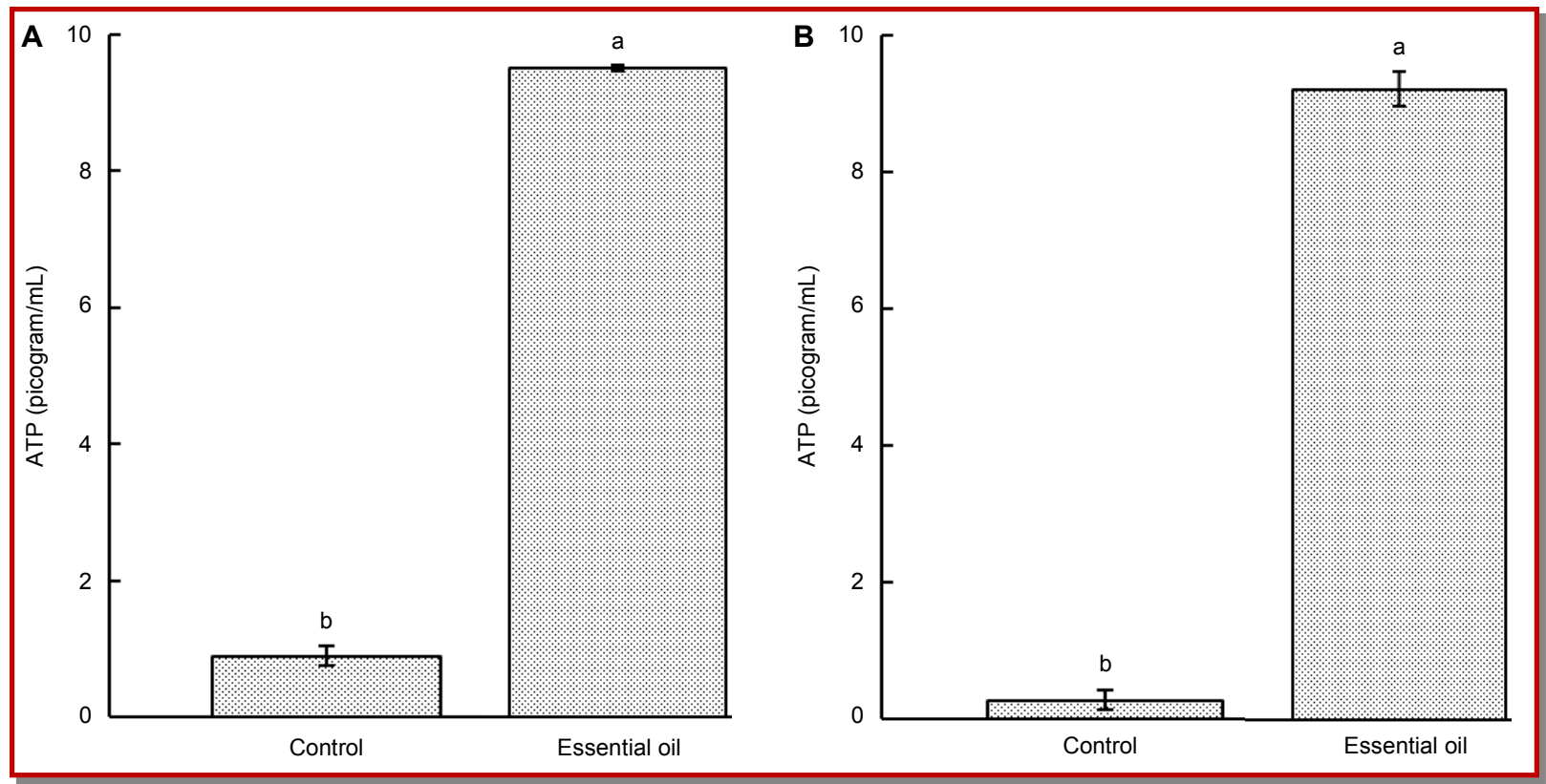

Figure 3: Effect of the Ginkgo biloba leaf essential oil on extracellular ATP concentration of B. cereus ATCC 13061 (A) and E. coli ATCC 43889 (B). Data are expressed as mean \pm SD $(n=3)$. Values with different superscripts are significantly different $(p<0.05)$

control cells of tested bacterial pathogens of B. cereus ATCC 13061 and E. coli ATCC 43889 cells during the study. It was found that potassium ion efflux of Gram positive bacteria was higher than Gram negative bacteria.

Another strategy for determining the mode of action of G. biloba leaf essential oil against Gram positive and negative bacteria of food-borne origin was performed on the basis of release of 260-nm absorbing materials from the treated cells of B. cereus ATCC 13061 and E. coli ATCC 43889. The optical density $\left(\mathrm{OD}_{260} \mathrm{~nm}\right)$ of the culture filtrates of B. cereus ATCC 13061 and E. coli ATCC 43889 cells exposed to G. biloba leaf essential oil at minimum inhibitory concentration revealed an increasing release of $260 \mathrm{~nm}$ absorbing materials with respect to exposure time (Figure 5). However, no changes in the optical density of untreated (control) cells of B. cereus ATCC 13061 and E. coli ATCC 43889 were observed during the study. After $60 \mathrm{~min}$ of treatment, approximately more than 2-fold increase was observed in the optical density of the bacterial cell culture filtrate treated with G. biloba leaf essential oil (Figure 5a,b). This directly indicates the confirmation of leakage of $260 \mathrm{~nm}$ absorbing materials from the bacterial cells treated with G. biloba leaf essential oil.

\section{Discussion}

Food-borne diseases create a significant hazard to human health and the economy of individuals (Kordali et al., 2005). Food safety is an essential concern of both consumers and the food industry, especially as the number of reported cases of food-borne infections continues to increase (Alzoreky and Nakahara, 2003). Frequent outbursts of food-borne diseases have sustained the demand for preservation systems that limit the proliferation of food-borne pathogens in processed foods. Currently, many food additives i.e., benzoic acid and sorbic acid are used in the food industry. Although these synthetic preservatives are effective, they can be detrimental to human health and consequently an increasing number of consumers choose food products which are preservative-free or contain only trace amounts (Kim et al., 2005). The exploration of naturally occurring antimicrobials for food preservation receives increasing attention due to consumer awareness of natural food products and a growing concern of microbial resistance towards conventional preservatives (Draughon, 2004).

The plant-based essential oils have been used since decades in food preservation and pharmaceuticals as alternative medicines and natural therapies (Devasagayam et al., 2004). Essential oils are fairly complex mixtures, which are well known to possess varying antimicrobial effects (Bajpai et al., 2012). They generally show selective toxicity towards various pathogens and are relatively safe both to animals and humans (Bajpai et al., 2012). In complex mixtures, synergism of individual components is also expected so that micro-organisms hardly can develop resistance towards essential oils. Their mode of action works on various bacterial sites inside and outside the cell (Burt, 2004). Various studies on different foods and food environments showed significant antimicrobial effects of essential oils both in vitro and in vivo (Burt, 2004). 

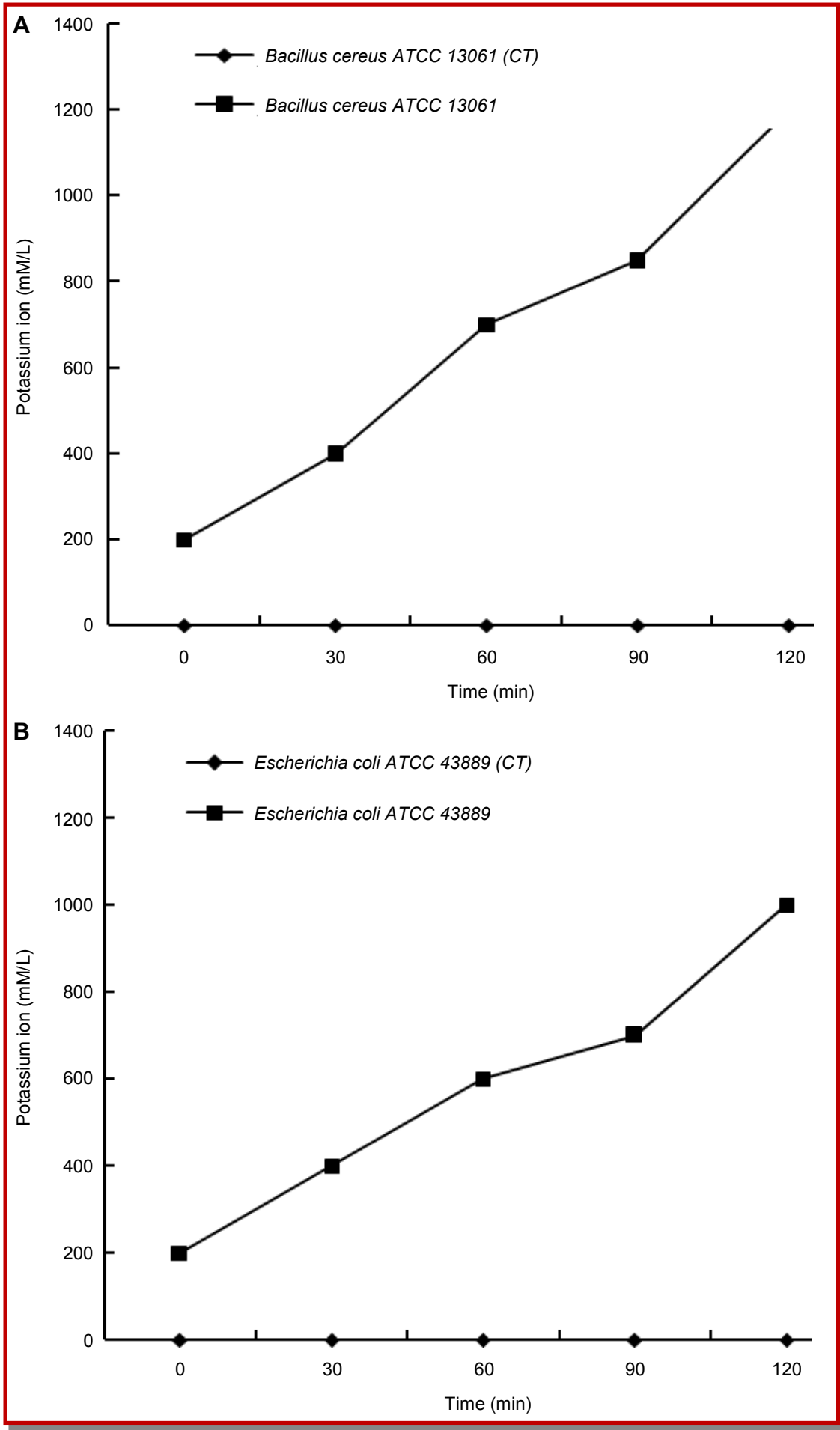

Figure 4: Effect of the Ginkgo biloba leaf essential oil on the leakage of potassium ions from the tested food-borne pathogenic bacteria of B. cereus ATCC 13061 (A) and E. coli ATCC 43889 (B). CT: Control without treatment

Hence, it is worth-while to scientifically explore these traditional medicinal plants to improve the quality of healthcare systems. Also, the renewal of interest in food industry and increasing consumer demand for safe and effective natural products means that scientific data on plant-based essential oils are required.
In this study, a microwave-assisted extraction method, which selectively extracts target compounds from various raw materials, was applied for the isolation of G. biloba leaf essential oil. The main advantages of the microwave extraction over the conventional extraction techniques are its higher extraction efficiency, 


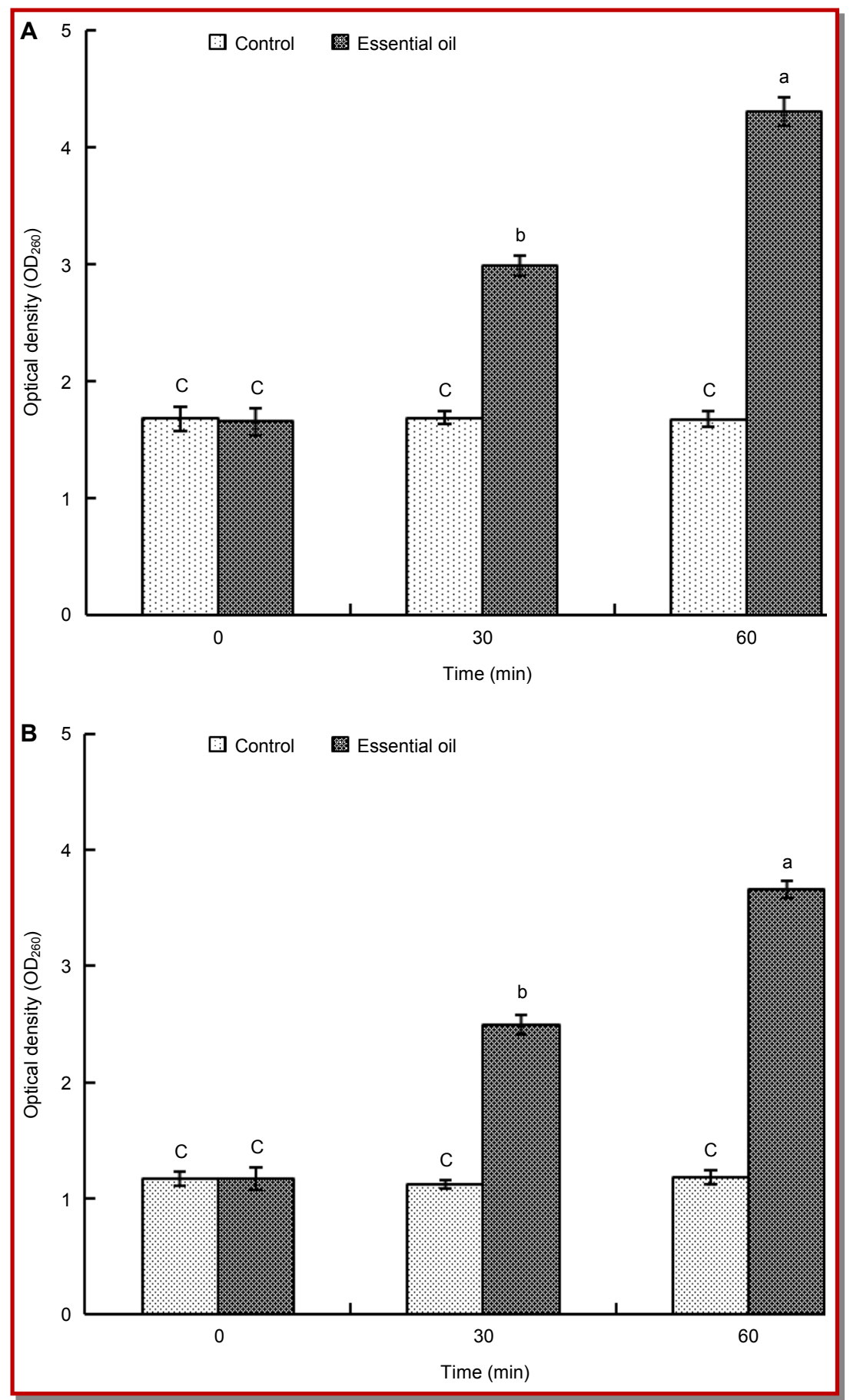

Figure 5: Effect of the Ginkgo biloba leaf essential oil on the release rate of $260 \mathrm{~nm}$ absorbing material from B. cereus ATCC 13061 (A) and E. coli ATCC 43889 (B). Data are expressed as mean \pm SD $(n=3)$

environmental friendliness, no provision for handling potentially hazardous fumes, less time consumption, higher recovery rate, better reproducibility and lesser sample manipulation during the extraction process (Ayuso et al., 2001). Especially, this technique has a great advantage over extracting essential oils from hardshell nuts or the rigid parts of the plants without any breakage of the tissues prior to extraction.
In this study, the results of the antibacterial screening showed that G. biloba leaf essential oilhad strong and consistent inhibitory effects against the panel of tested foodborne pathogens as confirmed by the inhibitory effect of G. biloba leaf essential oil showing different susceptibility rate against the tested food-borne pathogens. Essential oils are volatile and odorous principles of plant secondary metabolism which have 
wide applications in food flavoring and preservation industries (Bajpai et al., 2012). In recent years, several researchers have reported that terpenes and their oxygenated derivatives, which are the major components of essential oils, exhibit potential antimicrobial activity (Cakir et al., 2004). These findings strongly support the outcomes of this study since G. biloba leaf essential oil was also found to contain terpenes, terpenoids and their respective hydrocarbons, confirming its efficacy as natural antimicrobial agent.

Furthermore, the results from viable count assay revealed that exposure of G. biloba leaf essential oil had a rigorous effect on the cell viability of the tested bacterial pathogens. The G. biloba leaf essential oil exerted its maximum bactericidal activity as evident by the significant reduction in microbial counts and complete inhibition of B. cereus ATCC 13061 and E. coli ATCC 43889 cell viable counts observed at 160 and 200 min exposure, respectively. Previously we confirmed the inhibitory effects of various plant-based essential oils on the cell viability of food-borne pathogenic bacteria (Bajpai et al., 2008; Bajpai et al., 2009; Bajpai et al., 2012). Similar to our findings, other essential oils also exerted inhibitory effects against various foodborne pathogens (Al-Reza et al., 2010).

Membrane permeability and surface characteristic parameters were used to determine the mode of action of G. biloba leaf essential oil against the tested bacterial pathogens of food origin including Gram positive and Gram-negative bacteria which included determination of extracellular ATP concentration, loss of $260 \mathrm{~nm}$ absorbing materials and leakage of potassium ions as well as determination of effect of G. biloba leaf essential oil on cell wall structure of the tested food-borne pathogens using SEM analysis associated with morphological changes and surface characteristics.

The physical and morphological alterations in cell wall structure were investigated by SEM analysis. The G. biloba leaf essential oil revealed its inhibitory effect as confirmed by the severe morphological alterations on the cell wall of the tested food-borne pathogens leading to disruption and lysed cell formation. Previously such morphological alterations have been observed for various kinds of test organisms when treated with different essential oils (Zhu et al., 2005; Bajpai et al., 2009). These morphological alterations in bacterial cells might be occurred due to the effect of G. biloba leaf essential oil on membrane integrity, thereby resulting in the lysis of bacterial cell wall followed by the loss of intracellular dense material on the surface of treated cells, as evident by the previous findings (Ghannoum, 1988). Changes in membrane fluidity are usually occur due to alterations in membrane lipid composition (Sikkema et al., 1994) and are thought to be a compensatory mechanism to counter the lipid disordering effects of the treatment agent. The literature suggests that the active components of the essential oil might bind to the cell surface and then penetrate to the target sites possibly the plasma membrane and membrane-bound enzymes, resulting in the disruption of cell wall structure (Zhu et al., 2005; Bajpai et al., 2009).

On the other hand, ATP is used for many cell functions including transport work moving substances across cell membranes which might be a potential target parameter to understand the mode of action of antimicrobial agents. In prokaryotes, the cell membrane takes care of not only the cell's energy-conversion needs, but also nutrient processing, synthesizing of structural macromolecules and secretion of the many enzymes needed for life. The results of our study on the determination of extracellular ATP concentration showed an increasing rate of extracellular ATP concentrations after B. cereus ATCC 13061 and E. coli ATCC 43889 cells exposed to G. biloba leaf essential oil at minimum inhibitory concentration. This might be occurred because of significant impairment in membrane permeability of the tested bacteria by G. biloba leaf essential oil, which caused the intracellular adenosine 5'-triphophate leakage through defective cell membrane. Previously similar findings on this phenomenon have also been reported for various antibacterial agents (Herranz et al., 2001). In addition, Burt (2004) reported that exposure of $B$. cereus cells to some monoterpene alcohols resulted in decreased level of intracellular ATP while disproportionately increased the level of extracellular adenosine 5'-triphophate. Similarly Helander et al. (1998) found that B. subtilis ATCC 6633 cells treated with essential oil components resulted in the release of decreased level of intracellular adenosine $5^{\prime}$ triphophate pool and increased level of extracellular adenosine 5'-triphophate pool. In addition, the significant reduction in intracellular adenosine $5^{\prime}$ triphophate can be resulted due to the loss of inorganic phosphate across the compromised high permeable cell membrane or in virtue of the efforts made by the cell to recover the electrochemical gradient by proton motive force driven by the ATPase, an increased adenosine $5^{\prime}$ triphophate hydrolysis is established (Abbe et al., 1994; Chen and Montville, 1995). Subsequently, the antimicrobial effect might be established due to the inhibition of proton motive force, inhibition of mitochondrial respiratory and electron transfer chain, inhibition of substrate oxidation and active transportation, and loss of pool metabolites, as well as disruption of synthesis of DNA, RNA, protein, lipid and polysaccharides might also occur. Leakage of intracellular material is a general phenomenon induced by many antimicrobial substances results in cell death (Farag et al., 1989; Denyer, 1990).

Another apparent antimicrobial mode of action of G. biloba leaf essential oil was visualized by the 
confirmation on the leakage of $260 \mathrm{~nm}$ absorbing materials when the test food-borne pathogens exposed to G. biloba leaf essential oil at minimum inhibitory concentration. The macromolecules of a bacterial cell including DNA and RNA (nucleic acids) which reside throughout the interior of the cell, in the cytoplasm, are the key structural components. Measurement of specific cell leakage markers such as $260 \mathrm{~nm}$ absorbing materials is an indicative of membrane sensitivity to specific antimicrobial agent in relationship to unexposed cells. In this study, exposure of $B$. cereus ATCC 13061 and E. coli ATCC 43889 to GBEO caused rapid loss of $260 \mathrm{~nm}$ absorbing materials from the treated bacterial cells. The literature suggests that ability of antibacterial agent to kill bacteria might be a function of the stable interaction complex that is formed between drug-bound topoiso-merases and cleaved DNA (Kohanski et al., 2010). On such basis, studies have shown that strand breakage can occur in the presence of antibacterial agent. As a result of antibacterial action, the DNA replication machinery becomes arrested at blocked replication forks, leading to inhibition of DNA synthesis, which immediately leads to bacteriostasis and eventually cell death (Kohanski et al., 2010).

Furthermore, the antimicrobial mode of action of $G$. biloba leaf essential oil was also confirmed on the basis of leakage of the potassium ions from B. cereus ATCC 13061 and E. coli ATCC 43889 cells when exposed to G. biloba leaf essential oil at minimum inhibitory concentration. The bacterial plasma membrane provides a permeability barrier to the passage of small ions such as potassium ions which are necessary electrolytes, facilitating cell membrane functions and maintaining proper enzyme activity. This impermeability to small ions is maintained and even regulated by the structural and chemical composition of the membrane itself. Increases in the leakage of potassium ions will indicate a disruption of this permeability barrier. Maintaining ion homeostasis is integral to the maintenance of the energy status of the cell as well as membrane-coupled, energy-dependent processes such as solute transport, regulation of metabolism, control of turgor pressure and motility (Cox et al., 2001). Therefore, even relatively slight changes to the structural integrity of cell membranes can detrimentally affect cell metabolism and lead to cell death (Cox et al., 2001), potassium efflux and therefore, the extent of plasma membrane damage closely followed the effect on cell viability. This suggests that, in the case of B. cereus ATCC 13061 and E. coli ATCC 43889 , monitoring $\mathrm{K}^{+}$efflux and release of $260 \mathrm{~nm}$ absorbing materials may be the more sensitive indicators of membrane damage (Cox et al., 2001).

These findings assume that the accumulation of the essential oil components in the cytoplasm membrane causing instant loss of their integrity and become increasingly more permeable to protons and ions that might be responsible for the establishment of the antibacterial activity. Marked leakage of cytoplasmic material is used as indication of gross and irretrievable damage to the cytoplasm membrane and plasma membrane (Cox et al., 1998). Moreover, the observation that the amount of loss of $260 \mathrm{~nm}$ absorbing materials was as extensive as the leakage of potassium ions might indicate that the membrane structural damage sustained by B. cereus ATCC 13061 and E. coli ATCC 43889 cells resulted in release of macromolecular cytosolic constituents (Cox et al., 2001). Similarly the effect of essential oil component (carvacrol) on proton motive force of bacteria has been strongly correlated to leakage of various substances, such as ions, ATP, nucleic acids and amino acids (Helander et al., 1998).

Moreover, some essential oils exert greater inhibitory effect against broad range of pathogenic microorganisms. However, in this study, the Gram positive bacteria were found to be more susceptible to the $G$. biloba leaf essential oil than Gram negative bacteria. The hydrophilic cell wall structure of Gram negative bacteria is constituted essentially of lipo-polysaccharide that blocks the penetration of hydrophobic components and avoids the accumulation of essential oils in target cell membrane (Bezic et al., 2003). The single membrane of Gram positive bacteria is considerably more acessible to permeation by hydrophilic components of essential oil in the target sites. This might be the reason that Gram positive bacteria were found to be more sensitive to the G. biloba leaf essential oil than those of Gram negative bacteria. Similar findings on the susceptibility of various essential oils against foodborne pathogenic bacteria including Gram positive and negative bacteria have been reported previously (Bajpai et al., 2008; Bajpai et al., 2009; Bajpai et al., 2012).

The results of this study indicate that the essential oil derived from G. biloba leaves is able to disrupt membrane functions of both Gram positive and negative bacteria. We conclude that the G. biloba leaf essential oil exerts its inhibitory effect through permeabilization of the cell membrane associated with generalized membrane-disrupting effects, and this corresponds to a simultaneous reduction in the number of viable bacteria, increase of the $260 \mathrm{~nm}$ absorbing materials, and leakage of potassium ions with increased pool of extracellular adenosine 5 '-triphophate, these all data indicative of loss of membrane integrity. Moreover, the scanning electron microscopic observation also supports the above hypothesis, and strongly indicates the membrane disturbing activity of G. biloba leaf essential oil. This should lead to an effective application of the G. biloba leaf essential oil as a natural antimicrobial agent to control food-borne pathogens in food industries. Given the heterogeneous composition of G. biloba leaf essential oil and the antimicrobial activities of many of its components, it 
seems unlikely that there is only one mechanism of action or that only one component is responsible for the antimicrobial action.

\section{Acknowledgement}

This work was supported by the Yeungnam University Research Grant.

\section{References}

Abee T, Klaenhammer TR, Letellier L. Kinetic studies of the action of lactacin F, a bacteriocin produced by Lactobacillus johnsonii that forms poration complexes in the cytoplasmic membrane. Appl Environ Microbiol. 1994; 60: 1006-13.

Adam RP. Identification of essential oil components by gas chromatography/quadrupole mass spectroscopy. Carol Stream IL, Allured Publisher, 2001.

Al-Reza SM, Rahman A, Lee JH, Kang SC. Potential roles of essential oil and organic extracts of Zizyphus jujube in inhibiting foodborne pathogens. Food Chem. 2010; 119: 98186.

Alzoreky NS, Nakahara K. Antimicrobial activity of extracts from some edible plants commonly consumed in Asia. Int J Food Microbiol. 2003; 80: 223-30.

Ayuso GLE, Luque D, Castro MD. Employing focused microwaves to counteract conventional Soxhlet extraction drawbacks. Trends Anal Chem. 2001; 20: 28-34.

Bajpai VK, Rahman R, Kang SC. Chemical composition and inhibitory parameters of essential oil and extracts of Nandina domestica Thunb. to control foodborne pathogenic and spoilage bacteria. Int J Food Microbiol. 2008; 125: 117-22.

Bajpai VK, Al-Reza SM, Choi UK, Lee JH, Kang SC. Chemical composition, antibacterial and anti-oxidant activities of leaf essential oil and extracts of Metasequioa glyptostroboides Miki ex Hu. Food Chem Toxicol. 2009; 47: 1876-83.

Bajpai VK, Baek KH, Kang SC. Control of Salmonella in foods by using essential oils: A review. Food Res Int. 2012; 45: 72234 .

Bezic N, Skocibusic M, Dinkic V, Radonic A. Composition and antimicrobial activity of Achillea clavennae L. essential oil. Phytother Res. 2003; 17: 1037-40.

Braquet P. The ginkgolides: Potent platelet-activating factor antagonists isolated from Ginkgo biloba L.: Chemistry, pharmacology and clinical applications. Drugs Future. 1987; 12: 643-99.

Burt S. Essential oils: Their antibacterial properties and potential applications in foods: A review. Int J Food Microbiol. 2004; 94: 223-53.

Cakir A, Kordali S, Kilic H, Kaya E. Antifungal properties of essential oil and crude extracts of Hypericum linarioides Bosse. Biochem Syst Ecol. 2005; 33: 245-56.

Cakir A, Kordali S, Zengin H, Izumi S, Hirata T. Composition and antifungal activity of essential oils isolated from Hypericum hyssopifolium and Hypericum heterophyllum. Flav
Frag J. 2004; 19: 62-68.

Carson CF, Mee BJ, Riley TV. Mechanism of action of Melaleuca alternifolia (tea tree) oil on Staphylococcus aureus determined by time-kill, lysis, leakage, and salt tolerance assays and electron microscopy. Antimicrob Agents Chemother. 2002; 46: $1914-20$

Chen Y, Montville TJ. Efflux of ions and ATP depletion induced by pediocin PA-1 are concomitant with cell-death in Listeria monocytogenes Scott-A. J Appl Bacteriol. 1995; 79: 684-90.

Cox SD, Gustafson JE, Mann CM, Markhan JL, Liew YC, Hartlnd RP. Tea tree oil causes $\mathrm{Kp}$ leakage and inhibits respiration in Escherichia coli. Lett Appl Microbiol. 1998; 26: 355-58.

Cox SD, Mann CM, Markhan JL, Gustafson JE, Warmington JR, Wyllie SG. Determining the antimicrobial action of tea tree oil. Molecules 2001; 6: 87-91.

Davidson PM. Chemical preservatives and natural antimicrobial compounds. In: Food microbiology: Fundamentals and frontiers. Doyle MP, Beuchat LR, Montville TJ (eds). Washington DC, American Society for Microbiology, 1997, pp 520-56.

Denyer SP. Mechanisms of action of biocides. Int Biodeterior. 1990; 26: 89-100.

Denyer SP, Hugo WB. Biocide-induced damage to the bacterial cytoplasmic membrane. In: Mechanisms of action of chemical biocides. Denyer SP, Hugo WB (eds). The society for applied bacteriology. Technical series No 27. Oxford, Blackwell Scientific Publication, 1991, pp 171-88.

Devasagayam TPA, Tilak JC, Boloor KK, Sane KS, Ghaskadbi SS, Lele RD. Free radicals and anti-oxidants in human health: Current status and future prospects. J Assoc Physic India. 2004; 52: 794-804.

Draughon FA. Use of botanicals as biopreservatives in foods. Food Technol. 2004; 58: 20-28.

Farag RS, Daw ZY, Hewedi FM, El-Baroty GSA. Antimicrobial activity of some Egyptian spice essential oil. J Food Prot. 1989; 52: 665-67.

Ghannoum MA. Studies on the anticandidal mode of action of Allium sativum (garlic). J Gen Microbiol. 1988; 134: 2917-24.

Han T, Nazarenko Y, Lioy PJ, Mainelis G. Collection efficiencies of an electrostatic sampler with superhydrophobic surface for fungal bioaerosols. Indoor Air. 2011; 21: 110-20.

Helander IM, Alakomi HL, Latva-Kala K, Mattila-Sandholm T, Pol I, Smid EJ, Gorris LGM, Wright VA. Characterization of the action of selected essential oil components on Gramnegative bacteria. J Agric Food Chem. 1998; 46: 3590-95.

Herranz C, Chen Y, Chung HJ, Cintas LM, Hernandez PE, Montville TJ, Chikindas ML. Enterocin P selectively dissipates the membrane potential of Enterococcus faecium T136. Appl Environ Microbiol. 2001; 67: 1689-92.

Huang D, Ou B, Prior RL. The chemistry behind anti-oxidant capacity assays. J Agric Food Chem. 2005; 53: 1841-1856.

Huh H, Staba EJ. Botany and chemistry of Ginkgo biloba L. J Herbs Spices Med Plants. 1992; 1: 92-124. 
Kalemba D, Kunicka A. Antibacterial and antifungal properties of essential oils. Curr Med Chem. 2003; 10: 813-29.

Kaur A, Nain P, Nain J. In vitro anti-oxidant and antimicrobial activity of Ginkgo biloba bark extract. Int J Nat Prod Sci. 2012; 1: 168 .

Kim YS, Hwang CS, Shin DH. Volatile constituents from the leaves of Polygonum cuspidatum S. et $\mathrm{Z}$. and their antibacterial activities. Food Microbiol. 2005; 22: 139-44.

Kleijnen J, Knipschild P. Ginkgo biloba. Lancet 1992; 340: 113639.

Kockro RA, Hampl JA, Jansen B, Peters G, Scheihing M, Giacomelli R. Use of scanning electron microscopy to investigate the prophylactic efficacy of rifampin-impregnated CSF shunts catheters. J Med Microbiol. 2000; 49: 441-50.

Kohanski MA, Dwyer DJ, Collins JJ. How antibiotics kill bacteria: From target to networks. Nat Rev Microbiol. 2010; 8: 423-35.

Kordali S, Kotan R, Mavi A, Cakir A, Ala A, Yildirim A. Determination of the chemical composition and anti-oxidant activity of the essential oil of Artemisia dracunculus and of the antifungal and antibacterial activities of Turkish Artemisia absinthium, Artemisia dracunculus, Artemisia santonicum and Artemisia spicigera essential oils. J Agric Food Chem. 2005; 53: 9452-58.

Lee JY, Kim YS, Shin DH. Antimicrobial synergistic effect of linolenic acid and monoglyceride against Bacillus cereus and Staphylococcus aureus. J Agric Food Chem. 2002; 50: 2193-99.

Leonard CM, Virijevic S, Regnier T, Combrinck S. Bioactivity of selected essential oils and some components on Listeria monocytogenes biofilms. South Afr J Bot. 2010; 76: 676-80.
Mazzanti G, Mascellino MT, Battinelli L, Coluccia D, Manganaro M, Saso L. Antimicrobial investigation of semipurified fractions of Ginkgo biloba leaves. J. Ethanopharmacol. 2000; 71: 83-88.

Naik SR, Panda VS. Anti-oxidant and hepatoprotective effects of Ginkgo biloba phytosomes in carbon tetrachloride-induced liver injury in rodents. Liver Int. 2007; 27: 393-99.

Naik SR, Pilgaonkar VW, Panda VS. Evaluation of anti-oxidant activity of Ginkgo biloba phytosomes in rat brain. Phytother Res. 2006; 20: 1013-16.

Panda VS, Naik SR. Cardioprotective activity of Ginkgo biloba phytosomes in isoproterenol-induced myocardial necrosis in rats: A biochemical and histoarchitectural evaluation. Exp Toxicol Pathol. 2008; 60: 397-404.

Paulo L, Ferreira S, Gallardo E, Queiroz JA, Domingues F. Antimicrobial activity and effects of resveratrol on human pathogenic bacteria. World J Microbiol Biotechnol. 2010; 26: 1533-38.

Pietri S, Maurelli E, Drieu K, Culcasi M. Cardioprotective and anti-oxidant effects of the terpenoid constituents of Ginkgo biloba extract (EGb 761). J Mol Cell Cardiol. 1997; 29: 733-42.

Sati SC, Joshi S, Antibacterial activities of Ginkgo biloba leaf extracts. Scient. World J. 2011; 11: 2237-42.

Sikkema J, De Bont JAM, Poolman B. Interactions of cyclic hydrocarbons with biological membranes. J Biol Chem. 1994; 269: 8022-28.

Zhu SY, Yang Y, Yu HD, Ying Y, Zou GL. Chemical composition and antimicrobial activity of the essential oils of Chrysanthemum indicum. J Ethnopharmacol. 2005; 96: 151-58. 